Asia Proceedings of Social Sciences

(APSS)

www.readersinsight.net/APSS

\title{
Human Resources: Its Contribution to Economic Development in Indonesia
}

\section{Wilson Bangun}

Faculty of Economics, Maranatha Christian University

Indonesia

Corrosponding author's Email: wilson.bangun@yahoo.co.id

Peer-review under responsibility of $4^{\text {th }}$ Asia International Conference 2018 editorial board (http://www.utm.my/asia/our-team/) (C) 2018 Published by Readers Insight Publisher, lat 306 Savoy Residencia, Block 3 F11/1,44000 Islamabad. Pakistan, info@ readersinsight.net

This is an open access article under the CC BY-NC-ND license (http://creativecommons.org/licenses/by-nc-nd/4.0/). 


\section{Research Highlights}

The type of research used is explanatory research. This study proposes hypotheses and results that show a positive influence between the factors of production of human resources and capital towards economic growth in Indonesia.

\section{Research Objectives}

Economic growth can be used as a measure of development that reflects the welfare of society in a country. The source of economic growth used in this study uses a production factors approach, namely capital, human resources, and technology. Human resources make the biggest contribution compared to capital production factors and technology towards Indonesia economic growth.

This study aims to determine the magnitude of the contribution of human resources to Indonesia economic growth.

\section{Methodology}

To measure the magnitude of the contribution of each production factors to Indonesia economic growth, the Neo Classical economic growth model was used as proposed by Abramovit and R.M. Solow using the Cobb Douglas production function that has been changed in a multiple regression equation: $\log \mathrm{Yy}=\log \mathrm{a}+\alpha \log \mathrm{C}+\beta \log \mathrm{L}$. The type of data used is secondary data in the time seies regarding the devolopment of the human resource using data of laborforce, capital the using data of domestict and foreign investment, and gross domestict product, from 2004-2016. To the determine the magnitude of the influence of the production fctors of human resource and capital on Indonesia economic growth, it was processed using SPSS.20 program. Further more, to measure the contribution of each production factor to Indonesia economic growth, the Alfian Lains formula was used with the Dession method as follows: $\mathrm{Cr} \mathrm{Xi}=\frac{r X i}{r Y}$ xcoefesienXi 


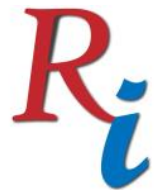

\section{Asia Proceedings of Social Sciences \\ (APSS) \\ www.readersinsight.net/APSS}

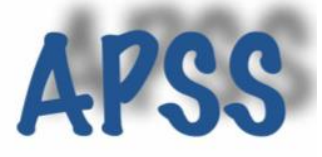

is data on the development laborforce of Indonesian originating from world bank, domestic investment and planting foreign capital comes from the world bank and the finance ministry of the Republic of Indonesia, Gross Domestic Product sourced from the world bank.

\section{Results}

The results of the study show that the factors of production of human resources and capital have a positive influence on Indonesia economic growth of 96.30 percent. The value of labor elasticity to GDP is 7.755 , which means that if there is an increase in energy productivity by 10 percent, then economic growth will increase by 77.55 percent. For capital production factors, with an elasticity value of 0.041 , there is only economic growth of 4.10 percent, if there is an increase in capital productivity by 10 percent. Whereas, for the factor of technology production is the result of a reduction between national income and the factor of labor production after being added to capital which is equal to 1.64 percent. The results of this study indicate that in Indonesia there is a strong influence between the factors of human resources and capital on GDP, while the factors of technology production are small. Technological developments in Indonesia still lag behind compared to India, Singapore, Malaysia, Thailand and the Philippines.

\section{Findings}

The factor of human resource production provides the biggest contribution to Indonesia economic growth. However, human resource in Indonesia is dominated by an unskilled human resource category of 73.12 percent, while the remaining 26.88 percent is classified as skilled human resources, it causes GDP of Indonesia is low. Based on the Neo Classical flow, capital and human resource factors make a biggest contribution to Indonesia economic growth, while the contribution of technological progress is low. Therefore, it is recommended that the Indonesian government must improve the quality of human resources through improvements in the education sector. 


\section{Acknowledgement}

Thank you to Maranatha Christian University for supporting me in completing this article. Thanks also to my wife and sons: Nita Sitepu, Christian Deswinta Bangun, and Soni Eduardo Bangun, in their moral and prayer support so that this scientific work was completed well. May the Lord Jesus Christ always give health and be with my family. Not forgetting to my parents, Basita Sitepu and Rahman Bangun (alm) who have always prayed for me so that I am always in good health.

\section{References}

Adelman \& Morris. (1973). Economic Growth and Social Equity in Developing Countries. Stanford: Stanford University Press.

Bangun, Wilson. (2014). "Human Development Index: Enhancing Indonesian Competitiveness in ASEAN Economic Community (AEC)." International Journal of the Computer, the Internet and Management 22(1): 42-47.

Bangun, Wilson. (2017). "Labor Productivity and Competitiveness (A Study: The Comparison of Indonesian with ASEAN)." International Journal of Applied Business and Economic Research 15(6): 289 -294.

Bangun, Wilson. (2018). "The Quality of Human Resource: A Study of Indonesian on the ASEAN Economic Community." Proceeding: The 2nd International Conference on Famili Business \& Entrepreneurship: 603 - 611.

Barro, Robert. (1996). "Inflation and Growth, Federal Reserve Bank of St. Louis." Review 78.

Heijazi, Walid \& Safarian. (1999). "Trade, Foreign direct investment, and R\&D spillovers." Journal of International Business Studies 30: 491-511.

Liu. Siler. Wang \& Wei. (2000). "Productivity spillovers from Foreign direct investment: evidence from UK industrylevel panel data." Journal of International Business Studies 31: 407-425.

Syrquin, Moises \& Chenery, Hollis. (1975). Patterns of Development. London: Oxford University Press. 